\title{
THE ROLE OF SOCIAL SUPPORT IN THE PERSISTENCE OF FIRST- YEAR FIRST-GENERATION AFRICAN STUDENTS IN A HIGHER EDUCATION INSTITUTION IN SOUTH AFRICA
}

\author{
S. Motsabi* \\ Department of Educational Psychology \\ e-mail: chillysoraya@gmail.com / https://orcid.org/0000-0002-9594-6389
}

\author{
B. M. Diale* \\ Department of Educational Psychology \\ e-mail: tumid@uj.ac.za / https://orcid.org/0000-0002-2007-4416
}

\section{A. Van Zyl*}

Academic Development Centre

e-mail: andrevz@uj.ac.za / https://orcid.org/0000-0002-9568-1667

*University of Johannesburg

Johannesburg, South Africa

\section{ABSTRACT}

Although there are several studies on first-year, first-generation students internationally, their focus have predominantly been on reasons for dropping out, transition issues and the students' pre-entry attributes. However, few studies have focused on the first-year, first-generation African students (FYFGAS) in the African context. This article employed a qualitative inquiry to explore the role of social support in school retention among FYFGAS within the South African context. Twenty-three students in all participated in the individual interviews $(n=5)$ and in the focus group ( $n=18$ ) discussion. The interviews were based on questions where the research sought to understand the determinants and contributors to the students' persistence and success in their first year of study. Themes that emerged from the data analysis indicated the important role of the family, the community at home and at university and of peers in supporting and encouraging the FYFGAS in pursuing their studies throughout their first year. Findings of this study indicated the importance of social support towards the persistence and success for FYFGAS in their first year of study at university.

Keywords: first-year students, first-generation African students, higher education institution, parental support, peer support, persistence, resilience, social support

\section{INTRODUCTION}

Student success is a significant concern for Higher Education Institutions (HEI) in general and 
is measured through throughput rates or graduation rates (CHE 2013). Higher education institutions, students, parents, the larger community and the country at large, are all interested in the success and graduation rates in higher education. The interest of the various groups is motivated by differing reasons. For parents, it could be the possibility of having a child who will get a job and improve the family circumstances; for students it could be the prospect of creating a better future for themselves; and for the country, it could be the possibility of improving the economy due to a better educated society. The South African higher education sector has grown by 10,5 per cent between 2010 and 2015 and the highest growth was within the African population which was 16,8 per cent (CHE 2016). The majority of these African students are students whose parents have not attended higher institutions of learning and are regarded as first-generation (Van Zyl 2010, 209). Even though there has been this increase of African first-generation students, there has also been a concomitant failure and attrition rate within this group (CHE 2016, 63).

Numerous reasons are suggested for the high failure rate and attrition in the first year. These include the difficulty of transition to higher education (Leibowitz, Van der Merwe and Van Schalkwyk 2012), the under-preparedness of first year students (Tinto 2008), financial difficulties (Letseka et al. 2009), wrong choice of courses and many more (CHE 2013). It is with these reasons in mind, that this study sought to investigate what social resources contribute to the success of those students who become resilient and persistent throughout their first year of study. Before a discussion of first-year first-generation African students is undertaken, there is a need first to understand what and who first-generation students (FGS) are in international literature, which will form a foundation for the discussion of FYFGAS.

\section{FIRST-GENERATION STUDENTS (FGS)}

First-generation university students tend to be non-traditional as in they are older (over the age of 24), mostly female, students of colour, and students from minority populations in the USA. They also come from poor socio-economic classes, commute to campus, hold part-time jobs and are financially independent (Duke-Benfield 2015) and have family responsibilities and are employed (Hodges-Payne 2006; Rood 2009; Tinto 2008). These students are likely to stay with family and, therefore, commute to campus (Engle 2010). In Western countries, the majority of FGS are students of colour (Choy 2001; Higher Education Research Institute 2007; Hurtado 2007; Ishitani 2006; Pascarella and Terenzini 2005; Soria and Gorny 2012; Warburton, Bugarin and Nunez 2001). Ecklund (2012) states that 38 per cent of FGS in the USA are of Hispanic and Latino origin, 23 per cent are of African-American descent, 17 per cent are Native Americans, 19 per cent are Asian-American students and 13 per cent are Caucasian students. 
In Australia, FGS are mostly Aboriginals (Hutchens, Deffendall and Peabody 2011; O'Shea 2016). In South Africa, first-generation students are from historically disadvantaged students who have been denied systematic access to higher education (Bangeni and Kapp 2007; Mdepa and Tshiwula 2012; Vincent and Idahosa 2014). Van Zyl (2010) and Siyengo (2015) indicate that African students form the majority of first-generation students in higher education. In this article, the focus is on first-year first-generation African students (FYFGAS). FYFGAS are Black South African students as classified in the SA population Registry (Mda 2012), whose parents have not attended university or have no education at all (Jones et al. 2008, 46). The majority are the first of their siblings in the family to attend university. They come from families in which the understanding of academic norms, expectations, and demands are different from families in which at least one parent attended a higher education institution (Heymann and Carolissen 2011).

The student characteristics of South African FYFGAS of Black African heritage, tend to live in extended family households, single-parent families (Steyn 2016) or child-headed homes (Pillay 2016). The majority come from rural areas, and black townships and generally are from low socio-economic contexts, where parents are under-employed or completely unemployed (Statistics South Africa 2014) or from families that experience extreme poverty (Breier 2010; Jones et al. 2008). Moreover, they come from poorly resourced schools and are not being adequately prepared for higher education (Van Broekhuizen, Van der Berg and Hofmeyer 2016) and are motivated to improve their family circumstances with qualifications that would enable them to get better jobs to achieve their goals.

The majority of FGS are mostly non-English speakers (Engle, Bermeo and O'Brien 2006; Warburton et al. 2001) and, therefore speak a different language at home from the common language of teaching and learning. Furthermore, Engle et al. (2006) and Prospero and VohraGupta (2007) state that FGS are perceived to be under-prepared for higher education and their experiences differ remarkably from those of their second-generation peers. In trying to navigate higher education, their chances of failing, dropping out and not completing their studies successfully increases. Therefore, social support may be critically important and studies are needed on how the FYGAS perceive the role of social support in their educational success.

\section{SOCIAL SUPPORT}

Social support has been described as support available to an individual through social ties with other individuals, the community and groups (Ozbay et al. 2007). Social support can be at several levels: the family, community and other sources (MacGeorge, Samter and Gillihan 
2005). This could be emotional support which indicates care and concern or even instrumental support through which the student receives financial support, food, clothing, as well as other resources (Malecki and Demaray 2006). It also involves information support which entails sharing of information, counselling and guidance in a way that promotes self-sufficiency (Van Breda 2001).

Social support and persistence of FYFGAS could be viewed from the lens of systems theory. In this study, social support and resilience are embedded within Bronfenbrenner's BioEcological Theory (1979) as indicated in Figure 1. This theory purports that children grow within families who are the immediate environment that offer them a reference point, where they learn about the world. It is in this environment where the student learns about the importance of higher education.

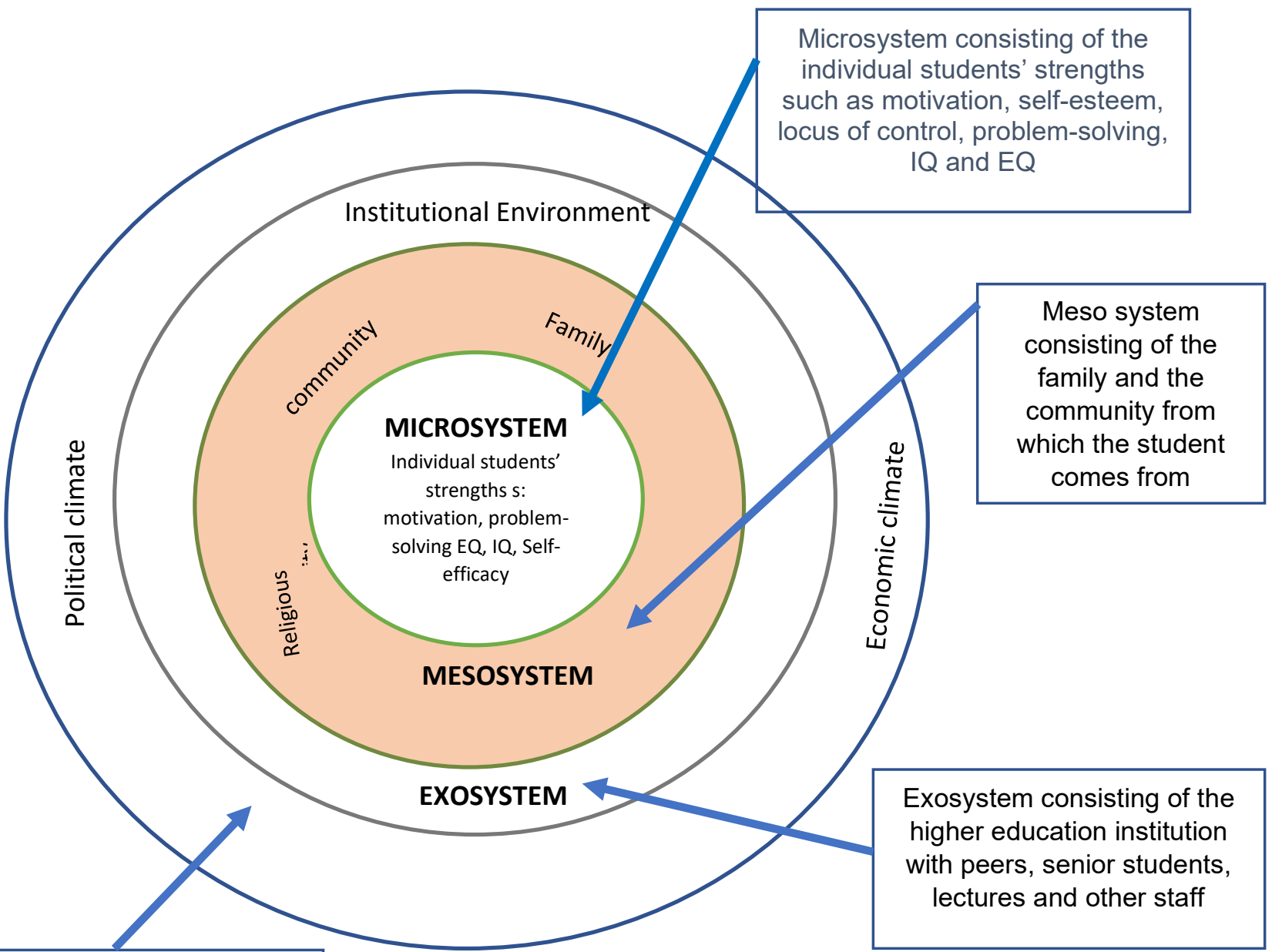

Macrosystem is comprised of policies from the institution and the state. The economic climate and the political climate

Figure 1: Bronfenbrenner's Bio-Ecological Systems in context (Adapted from Lewthwaite 2006, 19) 
The African culture prides itself in providing support in their communities. In African culture, social support is part of the "ubuntu" philosophy, which emphasises the importance of a group or community (Mangena 2016). Children grow up within a family which constitutes parents (mother and father), grandparents, aunts, neighbours, and older children who share in parenting. African people believe in the idiom "umuntu ngumuntu ngabantu" translated "a person is a person through other persons" (Mangena 2016, 67). Social support serves as a protective factor for first-year students through social networks which either provide financial support, information and other resources help buffer the students from the harshness of poverty and desperation of need (Malecki and Demaray 2006; Wilks and Spivey 2010). When faced with challenges of academia, they have a network of family, peers and other community members to depend on.

\section{Role of family}

Some studies suggest that family involvement and support are crucial for the success of firstgeneration students (Higher Education Research Institute 2007; Hudley et al. 2011). Some firstgeneration students report that they do not enjoy support from their families (Gibbons and Borders 2011; Sy et al. 2011; Mehta, Newbold and Rourke 2011), while other studies found that parents of FGS support them, but the difficulty is that they do not understand the structure and expectations of higher education (Gofen 2009; Higher Education Research Institute 2007).

The family socialises and influences the child on the benefits and importance of higher education (Bryan and Simmons 2009; Wang 2014). For instance, students whose parents have a higher education qualification, "perform better and persist more vigorously than those whose parents have no higher education" (Kuh et al. 2006, 22). Children develop internal resilience characteristics within the home, and it is these strengths that make the child steadfast and guided in his /her choices. Therefore, for FYFGAS to thrive in their university studies, their families have an essential role to play in supporting and encouraging them. Saenz and Berrera (2007) indicate that encouragement from parents, extended family and school counsellors, all play a pivotal role in choosing a post-secondary qualification for both first-generation students and their continuing counterparts.

\section{The role of community and social policy}

The community strongly influences the student as he/ she moves out of the home. Indeed, the relationships between these components influence the student's relationships. The student's previous community or community of origin include the school attended, their teachers, their church, and all other support structures. FYFGAS whose parents have no prior knowledge of 
higher education, depend on their school teachers and their friends for information about higher education. These people provide instrumental and informational support to the students.

Policies both at university and at their previous schools enable teachers and peers to influence the decisions of the first-year student within the higher education milieu. These relate to aspects of the Higher Education Institutions (HEIs) over which the student has no control, notably: regulations and policies. Such regulations and policies include, among others, the admission policies, assessment policies, academic support, academic regulations and expectations, financial aid, and other structural aspects of the HEIs.

A country's cultural values, laws, economic climate, political system, and government relate to the HE legislation, policies, and directives. These factors have an overarching, but indirect, impact on students' persistence and performance. Other studies have found that students often straddle two worlds; the community from which they originate, which could be supportive but is not, and the university environment where they have to find their footing (Guiffrida 2006; Winkle-Wagner 2009). The present study seeks to investigate the role of social support in the persistence and success of FYFGAS in higher education in the first year of study.

\section{METHODS}

\section{Research approach and design}

This study employed an interpretive-constructivist paradigm to understand FYFGAS subjective experiences of social support in their educational pursuits. Adopting an interpretive constructivist paradigm enabled the researchers to listen and interact with what the students said (Terre Blanche, Kelly and Durrheim 2006).

\section{Sampling}

The sample consisted of 23 FYFGAS participants who had completed their first semester and were continuing with their second semester in their first academic year at a large South African university. The participants were drawn from a cohort of FYFGAS registered in a common extended degree module, offered in three faculties in the university where the study was conducted. These were Humanities $(n=7)$, Science $(n=5)$ and Economics $(n=6)$ for the focus group interviews and five other participants who participated in individual interviews $(\mathrm{n}=2$ Economics; 2 Science; 1 Humanities) these had completed the first year and were registered for their second year at the university. In the total sample there were 13 females and 10 males, all students were between 18-20 years old.

Ethical clearance was granted by the university's research office (2013-014). The students 
consented to complete in-depth interviews from the three faculties. Respondents had to sign a consent form and were informed that they had a choice to withdraw from the study at any time. To preserve the participants' anonymity, pseudonyms were given for individual interviews and faculty-based labels given to focus group respondents.

\section{Data collection methods}

Data in this study were collected using structured face-to-face individual interviews with second-year students and focus groups interviews with first-year students. The interviews were conducted at a time suitable and convenient for the participants.

These two sets enabled us to dig deep into the shared experiences and related challenges that students face and the support they receive from their social systems. The interviews were conducted at a time suitable and convenient for the participants. The purpose of the study was explained to the participants who gave consent to participate. Data were audio recorded and later transcribed, and translated into English from the respondents who had preferred an African language as their response style.

\section{Data analysis}

Content data analysis was utilised. The three stages of analysis, as proposed by Miles and Huberman (2014), namely, data condensation, data display and drawing, and verifying conclusions were used. Firstly, transcripts of the recordings were made. Then these transcripts were manually coded, which is regarded as suitable pre-coding strategy for novice researchers (Saldaña 2009). The process was then transferred to Computer Assisted Qualitative Data Analysis Software (CAQDAS), where Atlas.ti version 7.5 was the electronic software used. As the iterative process coding continued, it was reviewed again and again. During this step of coding, the researcher re-read the transcribed interviews and created her own codes inductively and did not use the pre-determined codes (Nieuwenhuis 2007). These codes were developed with a conscious awareness of the research question, related to the potential determinants of and contributors to the persistence of first-generation students through the first year. The researcher continued to code and created memos which served as reflections of ideas and thoughts that related to the main questions asked during the interviews. The cyclical interactive process resulted in coding happening four times to ensure that all data was exhausted (Miles and Huberman 2014).

\section{Trustworthiness of qualitative data}

To ensure the credibility of the study, the interviews were conducted for $60-90$ minutes. The 
data were audio-recorded and transcribed. While qualitative research is not meant to be transferable and results generalised, in this study, the researchers provided thick and rich descriptions which would enable the reader to compare to similar situations. The dependability of this study was done through the alignment of data collection and data analysis methods. Finally, the conformability of this study was done through the maintenance of a paper trail of all interviews, the audio recording stored in a safe place and all transcripts and coding properly stored and kept. The study was coded twice; firstly, by the first researcher and verified by the two co-researchers.

\section{Ethical considerations}

Ethical clearance was granted by the university's research office (2013-014). To preserve the participants' anonymity, pseudonyms were given for individual interviews and faculty-based labels given to focus group respondents. Respondents had to sign a consent form and were informed that they had a choice to withdraw from the study.

\section{FINDINGS AND DISCUSSION}

The findings of this study resulted in three themes, namely, the family and its dynamics; the support from the community and; the support from the peers within the higher education institution. These themes and the evidence for them are presented below.

\section{Theme 1: Family dynamics and support}

One major motivator is improving the family situation. FYFGAS find that poverty is a stumbling block to their success and make the decision to persist so that they can create a better future for themselves and their siblings. One of the participants pointed this out by saying:

Joyce: "I just wanted to change ... I wanted to change the situation at home. I was raised by a single parent so you can imagine. We are two at home. My mom is not working, so I have to work harder to change the situation, that is why I'm here."

The other respondent from the Humanities group indicated the following:

Hum S3: "I want my siblings to have a better life and go to school, you know, pursue their dreams. Yes, that's what keeps me going."

These findings support Jehangir's (2010) findings that first-generation students are often concerned about improving their family situation. 
Students also dream big and realise they have the potential and would like to break the barriers as indicated by Candy who stated that: “... and I told myself, no, I see myself beyond that point of being a cashier. I want something more in my life."

Kennett, Reed and Lam (2011) found that students mentioned both internal and external reasons for attending university. First-generation students are also motivated to come to university to break the cycle of poverty (Bui 2002; Kennett et al. 2011). It is Joyce's wish to buy her mom a house as they all stay at her grandmother's house. Her second passion is to see her mother's excitement when she comes to the University for her graduation.

If institutions of higher learning realised the potential and the strength that FYFGAS have, they could zoom in on these characteristics to enhance the students' positive behaviour and provide strategies to encourage their success. In this way, they would give the students the support they need, which might not be available at home.

The participants revealed various factors within their families that encouraged them and also motivated them to pursue and continue with their studies. Situations that contributed to persistence could be either positive or negative, and they contribute in various ways, such as aspirations and planning for higher education, staying focused, not giving up in the face of challenges and providing financial support when needed.

Firstly, these students aspire to improve their family situation by obtaining their degrees and qualifications so that they can get jobs that would enable them to improve their social conditions. Their family conditions made them resolute in their pursuit of higher education. This is encapsulated in the following responses:

Hum S2: "The situation at home is my inspiration. The way I see my mother struggling with the four of us, it makes me keep going. I want my siblings to have a better life and go to school."

Candy: "My father couldn't afford school fees as well, because he was sick so and he was a tailor and being a tailor his money he made according to the orders they give. ... Those where the challenges I faced and still I went to school and told myself I'm going to finish this and nothing is going to stop me."

Secondly, the family provided encouragement and emotional support when things got tough, and when they thought of giving up. This is evidenced in the following statements:

Joyce: " $\quad$ u Mamami uyangi encourager everyday uluthi ngiqhubeke neskolo ngingayeki ngoba ayikho into engimele. Anginawo umsebenzi ongimele futhi akunamali ye investment ezophuma" [Translation: My mother encourages me to proceed and persist because there is no job waiting for me and also there are no family investments that I will inherit].

Hum S4: "My grandmother is not qualified, never went to school, but she wants a better life for 
me to go to school and get qualified."

Hum S1: "Yes, my aunt, because she is studying and she is a hard worker, you know, and she is determined. So, you know, she inspires me to also work hard and be determined and not let anyone and anything, you know, pull me down."

Thirdly, a family that includes both the parents and extended family assisted financially where students faced the frustration of giving up due to financial difficulties.

Hum S2: "My mom is also a single parent. She pays my school fees. Well, she opened an educational policy when I was one so that's helping and my dad pays for accommodation."

ECO S3: "My parents are paying for my fees."

Lastly, the role of extended family members in ensuring that these students remain focused and encouraged is invaluable. Many FYFGAS found that they had to depend mostly on relatives for information, emotional support and general encouragement. Relatives also served as a role model for these students, as indicated in the following statements:

Themba: "I do not have a mother, she died [when he was two years old], I only have a father and an aunt, and, but my aunt is like a mother to me. I am studying in order to meet my mother's wishes."

Hum S2 stated "that her aunt, who is also studying, provided her with an example of hard work".

While the majority of FYFGAS indicated their families' support, there are also those students who found that family dynamics play out negatively and are not supportive of their goal for higher education. These family members appeared to be determined to discourage and destroy the future aspirations of the students. Two students, who indicated poor support from their families, especially aunts and uncles, who have no idea of the benefits or concepts of higher education, succinctly stated this. Students seemed to understand the complexities of their families, and how and why their parents did not support them as much as they would like them to. These students indicated their resilience and determination in ensuring that they stay focused and persist throughout the first year.

Eco S2: "If you have people like uncles or brothers who are older than you and like partying and stuff like that, you have to study, but there is loud music ... they don't care. ... They did not finish school."

Eco S1: "I could say there was a fight in my family, my parents, you see. So, it's like I'm a stepson, so there was no support for me." 
Some students in this study indicated the role family played in motivating them to come to university and to stay at the university. The family has primary responsibility for child upbringing and socialisation. The family provides physical necessities, emotional support, learning opportunities, moral guidance and the building of self-esteem (Kumpfer and Summerhays 2006). Students who feel supported by their families tend to be more resilient and can withstand some negative influences. Mahani (2014) supports this finding and states that first-generation students who are supported by their families, perform much better and are more successful. The role of these significant others such as parents, extended family members, siblings and peers, have a positive effect on persistence.

Acknowledging that "it takes a village to raise a child", it is essential to recognise that because of their parents' educational levels, some students are encouraged and supported by their previous communities in seeking and maintaining their stay in higher education. The community could consist of high school teachers and principals, who helped with the application, pay fees or initial fees for students, grant them opportunities during the first year and generally support them emotionally, financially and instrumentally.

Furthermore, the community also consists of church leaders, academic and support staff within the HEI and other concerned adults. At the same time, the community also refers to adults within the university who ensure that the FYFGAS are assisted and supported to the best of their ability. The students indicated this support in the following manner.

Two of the participants stated that their school principals had even gone to the extent of paying their initial student fees. Several students also acknowledged the interest their teachers took in them, and how they had obtained the necessary forms and encouraged them to apply for university as well as financial assistance.

Sci 1 stated: "Without the intervention of my Principal, I would not be here", whereas

ECO S1 reported: "I went to the principal and told him my problems, and yeah, he agreed to fund me."

Without communities that work together and caring adults who realise their potential, firstgeneration African students might well be deprived of higher education.

Candy: "My teacher actually encouraged me as well to apply and not to go work because she recognised the potential in me, and then she gave me the money to apply, and then I came here and then I dropped it here. $J a$ (yes) that's how I applied." 
The students' support systems provided a variety of forms of support, namely emotional support from parents, friends and family; instrumental support from parents, especially fathers, friends, extended family members and teachers; appraisal support from friends and high school teachers; and informational support from previous school teachers and extended family members. These findings are similar to those of Pather et al. (2017) who found that firstgeneration students received both tangible and intangible support from their families. This network of support, which is discussed briefly, forms a buffer and serves to encourage persistence (Wilcox, Winn and Fyvie-Gauld 2005). These support systems are more effective if they are like an interlocking system where they seem to be connected in a way that the students experience the support, whether at home or school.

\section{Theme 2: Support from the community}

The university community, including the staff and various systems that are put in place to assist first-year students, also contribute to developing persistence in first-generation African students. Paul stated that the non-teaching staff assisted him in getting financial aid and in encouraging him not to drop out when things were tough. This is summarised in the excerpts below:

Paul: "This man, one good thing he did for me was taking me to my faculty and asking them to give me an extension for registration because registration was ending on the $31^{\text {st }}$ and the extension was until the $7^{\text {th }}$, regardless of whether my course was getting full or not."

"There is also a social worker in (Room number). That social worker, I would say knows my story, but I would sometimes not find her in her office. So, when I come to you is when she isn't available. I constantly go to her because it is easier now, she doesn't ask her any questions, she'll say: 'Paul, you're here' and would sort everything out for me."

Peers inside and outside the institution also play a significant role in supporting their peers and ensuring that they adapt positively and can integrate and learn to navigate higher education (HE), which also contributes to persistence. They also encourage fellow students to face challenges and overcome them.

Paul's story is an indication of the role his peers played in helping him stay at the university. He mentioned that when he was down and out and had no place to stay, his friends rallied together to support him.

Paul: "When things were really tough in the beginning of the year, my brothers that I go to church with could not help me with a place to stay because of the rules. But they offered me food and clothes because that time I did not even have a chance to sit down and do 
my laundry."

These friends did not only support and encourage the student, but they also sustained him in class attendance. The support was not only material, as they also helped the student to catch up on work covered in class that he had missed.

Candy: "When somebody needs something, they come to the other one, and when we need something we go, so we are close, we are very close cause we are actually friends, we help each other with school work so that no one is left behind."

These informal communities within the institution provide students with the skills and knowledge needed to deal with the "system". One Humanities student indicated that the support and encouragement from her friends, who were senior students within the institution, helped her to navigate and come to know the campus much quicker than she would have without their direction. These student friends helped the new students to understand the rules and the culture of the institution. Successful students have been found to surround themselves with like-minded people who have the same passion and determination. This ensures mutual support and guidance. Joyce expressed this by saying:

"People who share the same passion and attributes as you, people who have the same drive as yourself. People who are driven and know what they want in life, that's the crowd I hang around with. We all want to be successful."

Findings concerning the role of peers also indicate the conflict that FYFGAS face when dealing with friends from high school. Some participants reported that their peers in their communities were not supportive of their studies. These friends did not understand the complexities of higher education, and this caused the student to be alienated.

Joyce, Candy and Palesa who stated that some of their friends from home no longer connected with them as they no longer "spoke the same language", succinctly described this. In a way, they felt alienated from the peers they grew up with. This can be difficult, especially during the first year, when the student commutes between home and university. Palesa still finds herself spending some time with her peers even though they are not accommodative of her studies.

Palesa: "My former high school friends do not understand that I have more work from Varsity so I can no longer spend time with them. Ba re ke e ketsa betere (They say I think I am better)."

Candy: "In my community, I am the only one who decided to go to university, and all my friends 
chose to go and work. I don't keep contact with them because I now stay around varsity."

Because most students who participated in this investigation stayed with extended family, there was a communal responsibility of ensuring that the one at university became successful. Although some families recognised their inability to provide academic support to their children, some parents had begun to seek information to assist their children (Mahani 2014). It is in this regard that even though parents did not have a university education, they instilled expectations of going to university and when the students were enrolled, the same parents encouraged them and served as cheerleaders (Luedke 2014). While parents cannot assist with academic matters, their support is crucial in non-academic matters. Community support features quite prominently in this investigation. Some students indicated that someone from the community cared for them. Others stated the role of teachers and principals in ensuring that they remained at the university. In African culture, it is common to support children in the community. Africans, as a communal society, realise that one's achievement is not for the individual but the community. In this regard, participants also went back to their former schools to inform the other students about university life. Many looked up to the students as role models to succeed. This encouraged these students to do their best and to persist. This external motivation, although short-lived, is necessary initially to provide the students with momentum (Blackwell and Pinder 2014).

\section{Theme 3: Support from peers within the higher education institution}

Eco S1: "Since I was a first student at school, I went to the principal and told him my problems and yeah, he agreed to fund me." (Personal agency).

Hum S4: "Ok, I applied to the university because it was my dream and I believe that in coming to university, passing my matric was the first step. And then my second step was that coming to university, would open certain doors for me." (Personal agency).

Successful students emphasised the value of hard work. This hard work is an outcome of family modelling (Morales 2008). Candy and Paul understood that they needed the drive to work hard and work independently if they wanted to succeed.

Paul: "But then I pushed myself. I worked hard at school, you know, been to extra classes, got help from other students if I didn't understand."

Candy: "So I told myself, if he can succeed through hard work, I can also do it. Everyone can work hard; working hard is not like a gift that is given to certain people." 
Seeing other students and family members who are similar to one succeed, encouraged these students to believe they could also perform. Palesa, whose cousin was studying Chemistry at university, believes that, if her cousin could do it, she also could. She stated:

Palesa: "I have a cousin who studies here; he's doing Analytic Chemistry and is involved mo di project tse dintsi (in many projects), so he was like, well you might as well come to XXX ... and I thought, why not."

Another aspect of successful FYFGAS at the micro-level is the internal locus of control, which is the individual's belief about his ability to control events that affect him (Rotter 1966). This enables the students to take responsibility for their actions and their results. In support of this statement, one respondent said the following:

Paul: "On that Monday I went on Facebook and found a guy who has helped other students, and I approached him to help me with study fees."

Paul's story indicated a strong belief in taking charge of his destiny. He did not wait for things to happen but was aware that it was his life, and he was responsible for it. Paul showed that he was in control of his destiny as he stated that he could not blame others for his lack of success. Internal locus of control, which enables the student to attribute the outcomes of his actions to himself (Rotter 1966), is empowering and allows students to feel that they are in control of their destinies.

Internal locus of control is when students accept responsibility for their performance and understand that persistence and effort can help them overcome failures. This was supported in the following statement:

Candy: "You need to remember why you are there. You need to remember your goal, where you want to be years from now. Never lose focus because that's exactly what most of us do. We come here; we lose focus. So, don't lose focus. Keep your eye on the ball because, in the end, it will all be worth it."

This study revealed a balance between internal and external locus of control. Studies on the locus of control (Deniz, Tras and Eydagon 2009; Gifford, Briceño-Perriot and Mianzo 2006; Neill 2006) indicate that there is a relationship between academic achievement and locus of control.

Another personal attribute that encourages students to persevere and persist is motivation. Motivation can be either internal or external. While students manage and take control of their behaviour, major motivating factors are external. Even though students regard their studies as 
for their benefit, I found the majority of them indicated the external rewards that would be achieved after their studies. The following quotations supported this:

Eco S2: "For me, the reason why is that I wanted to further my studies and live a better life in the future so that I can also help my siblings."

Hum S5: "What persuaded me was because I wanted to have a better life because I know that outside there is a high rate of unemployment and without a qualification it's bad. And I'm the 1st person in my home, where I come from, to go to university and I want to make my parents proud."

University is a new experience for FYFGAS, and they may find it quite intimidating and overwhelming in the beginning. Terenzini and Reason (2005) believe that students enter into an organisation and have to deal with their peers. The peer environment represents the culture, values and beliefs of the institution. Peer influence is subtle and can influence the students' behaviour and performance in academic work. At the same time, peers can pressure the students into conforming to certain behaviours. The students, in this study, indicated that there was a degree of tension that they experienced as new students who were still trying to find their way. Persistence is achieved through self-knowledge and the ability to manage relationships that can be destructive. Braxton and Lee (2005) established that researchers have consistently found a link between social integration, institutional commitment, and subsequent student persistence.

One of the most important influences that friends and peers have is to assist students with their integration and the development of a sense of belonging. These findings support what Hausmann et al. (2009) found, that students experience a sense of family community with their peers. Furthermore, their findings indicated a direct relationship between a sense of belonging and goal commitment, institutional commitment and persistence. Astin (1993) found that peer groups were the most influential in personal and academic development. Integration for these FYFGAS was not difficult because they regarded themselves as being in the majority, not only as FGS but also because the majority of the student population is African. In that manner, there are many students with whom they share beliefs, values and attitudes.

\section{DISCUSSION}

This study yielded results that point at social support being a reliable resource for FYFGAS towards goal attainment. The students' support systems provided a variety of forms of support, namely emotional support, instrumental support, and informational support from family members. In this study, the findings indicated that parents provide different forms of support for their children. Mothers and grandmothers especially provided emotional support, by giving 
them encouragement and motivation in times of difficulty. Theron and Theron (2010) found similar results with Black township youth, who regard their mothers as their pillars of strength, as well as providing them with a sense of security. Most first-year students miss guidance on how and when to apply, how to get financial assistance and information about higher education because their parents may have little or no information (Jones et al. 2008). This study indicated that even though FYFGAS' parents lack the information they are supportive of their children's endeavours in pursuing higher education. These findings are similar to those of Pather et al. (2017) who found that first-generation students received both tangible and intangible support from their families. This network of support forms a buffer and serves to encourage persistence (Wilcox et al. 2005). These forms of support are essential for these students because that is where they draw their strength to persevere. Knowing that one's parents and one's family are cheering you on, can enable the student to venture into new beginnings. Students whose parents support them emotionally, feel psychologically stable and can face the challenges of higher education.

When parents are uneducated, it is the educated sector of the community that plays a significant role in assisting young students towards attaining their goals. Teachers and high school principals supported the students both emotionally and instrumentally by providing money for application fees and initial registration fees. Others provided information on applications and financial aid. This is important because it enabled the students to develop a sense of commitment when they felt that caring people surrounded them in their lives. Teachers that inspire students are invaluable to FYFGAS (Kajee 2018). At a community level, other African adults who seem to understand the desperation of African first-year students, provided most of the support. This supports the findings of Luedke (2014), who states that people from a similar environment support each other in understanding and navigating higher education. They provide the students with the necessary social capital and cultural capital that enables them to understand the system and succeed.

Academic success is related to academic and social integration within the institution (Tinto 2003). Therefore, peers play a significant role in supporting fellow students in higher education. FYFGAS who already had friends at university, found it easy to adapt and to negotiate HEI. One of the most important influences that friends and peers have, is to assist students with their integration and the development of a sense of belonging. These findings support what Hausmann et al. (2009) found, that students experience a sense of family community with their peers. Furthermore, their findings indicated a direct relationship between a sense of belonging and goal commitment, institutional commitment and persistence. Astin (1993) found that peer groups were the most influential in personal and academic development. 
Integration for these FYFGAS was not difficult because they regarded themselves as being in the majority, not only as FGS, but also because the majority of the student population is African. In that manner, there are many students with whom they share beliefs, values and attitudes. Studies by Guiffrida (2006) and Winkle-Wagner (2009) have found that students often straddle two worlds; the community from which they originate, and the university environment where they have to find their footing.

\section{IMPLICATIONS FOR HIGHER EDUCATION INSTITUTIONS (HEI)}

Higher education should be deliberate about the nature and context of their inclusive policies, catering for all the students within the institution.

Firstly, realising that FYFGAS have parents who do not know much about higher education, means that policies ought to be formulated that include the provision of such knowledge. This can be done online or through inviting parents to activities within the university, such as orientation days.

Institutions ought to have residences for first-year students where they can meet and work together with other students, both senior and peers, within the first year.

The majority of FYFGAS do not stay within the university residences and commute from home or communes. Therefore, universities should provide common areas where students can sit to share academic work or do things that young people do during their spare time. This may enable these students to be involved and to integrate into the university culture.

\section{CONCLUSION}

Social support contributes to the students' intention to persist. Knowing that there are family members that encourage one, a community that regards one as a role model and peers that continuously remind one of one's goals and support one while at university, motivates FYFGAS to achieve their goals and to persevere despite the challenges they face. In this way, students realise that there are others with whom they can overcome the obstacles that are presented on the way and succeed.

\section{REFERENCES}

Astin, A. W. 1993. What matters in college? Four critical years revisited. San Francisco: Jossey-Bass.

Bangeni, B. and R. Kapp. 2007. Shifting language attitudes in a linguistically diverse learning environment in South Africa. Journal of Multilingual and Multicultural Development 28: 253269.

Blackwell, E. and P. Pinder. 2014. What are the motivational factors of first-generation minority college students who overcome their family histories to pursue higher education? College Student Journal 
48: 45-56. http://www.ingentaconnect.com/content/prin/csj/2014/00000048/00000001/art00005 Google Scholar.

Braxton, J. M. and S. D. Lee. 2005. Toward reliable knowledge about student departure. In College student retention: Formula for student success. American Council of Education: Praeger Publishers.

Breier, M. 2010. From "Financial considerations" for "Poverty": Towards a reconceptualization of the role of finances in higher education student dropout. Higher Education 60: 657-670.

Bronfenbrenner, U. 1979. The ecology of human development: Experiments by nature and design. Cambridge, MA: Harvard University Press.

Bryan, E. and B. E. Simmons. 2009. Family involvement: Impacts on post-secondary educational success for first-generation Appalachian College students. Journal of College Student Development 50(4): 391-405.

Bui, K. V. T. 2002. First-generation college students at a Four-Year University: Background characteristics, reasons for pursuing higher education, and first-year experiences. College Student Journal 36: 3-11.

CHE see Council on Higher Education.

Council on Higher Education. 2013. A proposal for undergraduate curriculum reform in South Africa: The case for a flexible curriculum structure. Pretoria: CHE Publication.

Council on Higher Education. 2016. VitalStats. South African higher education reviewed-Two decades of democracy. Pretoria: CHE Publication.

Choy, S. 2001. Students whose parents did not go to college: Post-secondary access, persistence and attainment. Findings from the condition. Washington, DC: National Centre for Education Statistics (Ed).

Deniz, M. E., Z. Tras and D. Eydogan. 2009. An investigation of academic procrastination, locus of control and emotional intelligence. Educational Science: Theory and Practice 9(2): 623-632.

Duke-Benfield, A. E. 2015. Bolstering non-traditional student success. A comprehensive student aid system using financial aid, public benefits, and refundable tax credits (CLASP). https://www.clasp.org/sites/default/files/publications/2017/04/bolstering-non-trad-studentsformatted-paper-final.pdf

Ecklund, K. 2012. First generation college students in Christian Academia. Part 1: Academic and local church collaboration in the preparation of diverse students. Christian Higher Education 11(5): 331-341.

Engle, J., A. Bermeo and C. O'Brien. 2006. Straight from the source: What works for first-generation college students. Pell Institute for the Study of Opportunity in Higher Education. ERIC Number: ED501693.

Engle, J. 2010. Post-secondary access and success for first-generation college students. American Academic 3: 25-48.

Gibbons, M. and L. D. Borders. 2011. Prospective first-generation college students: A social-cognitive perspective. The Career Development Quarterly 58(3): 194-287.

Gifford, D., J. Briceño-Perriot and F. Mianzo. 2006. Locus of control: Academic achievement and retention in a sample of university first-year students. Journal of College Admission 191: 18-25.

Gofen, A. 2009. Family capital: How first-generation higher education students break the intergenerational cycle. Family Relations: Interdisciplinary Journal of Applied Family Science 58(1): 104-120.

Guiffrida, D. A. 2006. Toward a cultural advancement of Tinto's Theory. The Review of Higher Education 29(4): 451-472.

Hausmann, L. R. M., F. Ye, J. W. Schofield and R. L. Woods. 2009. Sense of belonging and persistence in white and African American first-year students. Research in Higher Education 50(7): 649-669.

Heymann, L. and R. Carolissen. 2011. The concept of first-generation student in the literature: 
Implications for South African higher education. South African Journal of Higher Education 25(7): 1378-1396.

Higher Education Research Institute. 2007. First in my family: A profile of first-generation college students at four-year institutions since 1971. HERI Research Brief. CA: University of Los Angeles.

Hodges-Payne, T. 2006. Perceptions of first-generation college students: Factors that influence graduate school enrollment and perceived barriers to attendance. Doctoral Dissertation. Pro-Quest Dissertations and Theses database UMI No. 3223320.

Hudley, C., R. Moschetti, A. Gonzalez, S. Cho, L. Barry and M. Kelly. 2009. College freshmen's perceptions of their high school experiences. Journal of Advanced Academics 20: 438-471.

Hurtado, S. 2007. Linking diversity with the educational and civic missions of higher education. ASHE Presidential Address. The Review of Higher Education 30(2): 185-196.

Hutchens, K., M. Deffendall and M. Peabody. 2011. Supporting first-generation college students. Kentucky Journal of Higher Education Policy and Practice 1(1).

Ishitani, T. T. 2006. Studying attrition and degree completion behaviour among first-generation college students in the United States. Journal of Higher Education 77: 861-865. http://findarticles.com/ p/articles/mi_hb 172/is_5_77ai_292896602

Jehangir, R. R. 2010. Higher education and first-generation students: Cultivating community, voice and place for the new majority. New York, NY: Palgrave MacMillan.

Jones, B., G. Coetzee, T. Bailey and S. Wickham. 2008. Factors that facilitate success for disadvantaged higher education students: An investigation into approaches used by REAP. NSFAS and selected higher education institutions. Athlone: Rural Education Access Programme (REAP).

Kajee, L. 2018. Teacher education students engaging with digital identity narratives. South African Journal of Education 38(2): 1-9.

Kennett, D., M. Reed and D. Lam. 2011. The importance of directly asking students their reasons for attending higher education. Issues in Educational Research 21(1).

Kuh, G. D., J. Kinzie, J. A. Buckley, B. K. Bridges and J. C. Hayek. 2006. What matters to student success: A review of the literature commissioned report for the National Symposium on Postsecondary Student Success: Spearheading a dialog on student success. National Postsecondary Cooperative Council.

Kumpfer, K. L. and J. F. Summerhays. 2006. Prevention approaches to enhance resilience among highrisk youth: Comments on the papers of Dishion and Connell and Greenberg. Annals New York Academy of Sciences 1094: 151-163.

Leibowitz, B., A. van der Merwe and S. van Schalkwyk. 2012. Focus on first-year success: Perspectives emerging from South Africa and beyond. Stellenbosch: SUN M.

Letseka, M., M. Cosser, M. Breier and M. Visser. 2009. Student retention and graduate destination: Higher education and labour market access and success. Cape Town: HSRC Press.

Lewthwaite, B. 2006. "I want to enable teachers in their change": Exploring the role of a superintendent on science curriculum delivery: Canadian Journal of Educational Administration Policy 52: 1-25. https://www.researchgate.net/publication/238080669

Luedke, L. 2014. We lift as we climb: Supporting first-generation students of color in navigating college. Doctoral dissertation, University of Wisconsin-Madison.

MacGeorge, E. L., W. Samter and S. J. Gillihan. 2005. Academic stress, supportive communication, and health. Communication Education 54(4): 365-372. doi: 10.1080/03634520500442236.

Mahani, S. 2014. A case study of the experiences of first-generation female students in the United Arab Emirates. Doctoral dissertation, Northcentral University.

Mangena, F. 2016. African ethics through Ubuntu: A postmodern exposition. Africology: The Journal of Pan African Studies 9(2): 66-79

Malecki, C. K. and M. K. Demaray. 2006. Social support as a buffer in the relationship between socioeconomic status and academic performance. School Psychology Quarterly 21(4): 375-395. 
Mda, T. V. 2012. Home away from home? African International students in South African Universities. Human Sciences Research Council, Pretoria, South Africa.

Mdepa, W. and L. Tshiwula. 2012. Student diversity in South African higher education. Widening Participation and Lifelong Learning 13(Special Issue): 19-33.

Mehta, S., J. Newbold and M. A. Rourke. 2011. "Why do first generation students fail?" College Student Journal 45(1): 20-35.

Miles, M. B. and A. M. Huberman. 2014. Qualitative data analysis: An expanded source. London: Sage Publications.

Morales, E. E. 2008. Academic resilience in retrospect: Following up a decade later. Journal of Hispanic Higher Education 4(4): 114-133.

Neill, J. 2006. What is locus of control? http://widerdom.com/psychology/loc/locusofcontrol/ whatis.html

Nieuwenhuis, J. 2007. Qualitative research designs and data gathering techniques. In First steps in research, ed. K. Maree and V. L. Pietersen, 69-97. Pretoria: Van Schaik.

O'Shea, S. 2016. Engaging first in family university learners. http://www.university worldnews.com/ article? story $=20161129232613901 \&$ mode

Ozbay, F., D. C. Johnson, E. Dimoulas, C. A. Morgan, D. Charney and S. Southwick. 2007. Social support and resilience to stress: From neurobiology to clinical practice. Psychiatry (Edgmont) 4(5): 35-40.

Pather, S., N. Norodien-Fataar, X. Cupido and N. Mkonto. 2017. First-year students' experience of access and engagement at a university of technology. Journal of Education (University of KwaZulu-Natal) 69. ISSN 2520-9868.

Pillay, J. 2016. Problematising child-headed households: The need for children's participation in early childhood interventions. South African Journal of Childhood Education 6(1): 1-8.

Pascarella, E. T. and P. T. Terenzini. 2005. How college affects students: A third decade of research (Volume 2). San Francisco, CA: Jossey-Bass.

Prospero, M. and S. Vohra-Gupta. 2007. First generation college students: Motivation, integration, and academic achievement. Community College Journal of Research and Practice 31(12): 963-975.

Rood, R. 2009. Driven to achieve: First-generation students' narrated experience at a private Christian College. Christian Higher Education Journal 8(3): 225-254.

Rotter, J. B. 1966. Generalized expectancies for internal versus external control of reinforcement. Psychological Monographs 80(1): 1-28.

Saenz, V. B. and D. S. Barrera. 2007. Findings from the 2005 College Student Survey (CSS): National aggregates. Los Angeles: Higher Education Research Institute.

Saldaña, J. 2009. The coding manual for qualitative researchers. Thousand Oaks, CA: Sage Publications Ltd.

Siyengo, N. 2015. The educational and psychosocial experiences of first-generation students. Master's dissertation, Stellenbosch University.

Soria, K. M. and L. S. Gorny. 2012. Defining first-generation students by degrees. Presented at the Association for Institutional Research Annual Forum. New Orleans. LA.

Statistics South Africa. 2014. Statistical release P0318 General Household Survey 2014. Pretoria: Government Printers.

Steyn, M. 2016. Towards a matrix for the advancement of black working-class students in South Africa's historically privileged universities. South African Journal of Higher Education 30(5): 176-195.

Sy, S. R., K. Fong, R. Carter, J. Boehme and A. Alpert. 2011. Parent support and stress among firstgeneration and continuing generation female students during the transition to college. https://doi.org/10.2190/CS.13.3

Terre Blanche, M., K. Kelly and K. Durrheim. 2006. Why qualitative research? In Research in practice: 
Applied methods for the social sciences, ed. M. Terre Blanche, K. Durrheim and D. Painter. Cape Town, South Africa: University of Cape Town Press (Pty) Ltd.

Terenzini, P. T. and R. D. Reason. 2005. Appraising the first year of college. A conceptual framework for studying college impacts. Paper presented at the meeting of the Association for the Study of Higher Education, Philadelphia, PA.

Theron, L. C. and A. M. C. Theron. 2010. A critical review of studies of South African Youth Resilience, 1990-2008. South African Journal of Science 106(7/8). http://www.sajs.co.za

Tinto, V. 2003. Student success and the building of involving educational communities. Syracuse, USA: HE monograph series. Syracuse University.

Tinto, V. 2008. Access without support is not opportunity. Keynote speech presented at the 36th Annual Institute for Chief Academic Officers, The Council of Independent Colleges, Seattle, Washington, 1 November 2008.

Van Breda, A. D. 2001. Resilience theory: A literature review. Pretoria: South African Military Health Services.

Van Broekhuizen, H., S. van der Berg and H. Hofmeyr. 2016. Higher education access and outcome for the 2008 national matric cohort. In the Stellenbosch Economic Working Papers 16/16 September 2016. Cape Town: University of Stellenbosch: Bureau of Economic Research.

Van Zyl, A. 2010. The predictive value of pre-entry attributes for student academic performance in the South African context. Doctoral dissertation, University of Johannesburg. http://hdl.handle.net/10210/5081

Vincent, L. and G. E. Idahosa. 2014. Joining the academic life: South African students who succeed at university despite not meeting standard entry requirements. South African Journal of Higher Education 28(4): 1433-1447.

Wang, T. 2014. "I'm the only person from where I'm from to go to college": Understanding the memorable messages first-generation college students receive from parents. Journal of Family Communication 14(3): 270-290. doi:10.1080/15267431.2014.908195.

Warburton, E. C., R. Bugarin and A. Nunez. 2001. Bridging the gap: Academic preparation and postsecondary success of first-generation students. Washington, DC: National Center for Education Statistics. https://nces.ed.gov/pubs2001/2001153.pdf

Wilcox, P., S. Winn and M. Fyvie-Gauld. 2005. "It was nothing to do with the university, it was just the people": The role of social support in the first-year experience of higher education. Studies in Higher Education Journal 30(6): 707-722.

Wilks, S. E. and C. A. Spivey. 2010. 2010. Resilience in undergraduate social work students: Social support and adjustment of academic stress. Social Work Education 29(3): 276-288.

Winkle-Wagner, R. 2009. The perpetual homelessness of college experiences: The tensions between home and campus for African American women. Review of Higher Education 33: 1-36. http://muse.jhu.edu/login?auth=0\&type=summary\&url=/journals/review_of_higher_education/v 033/33.1.winkle-wagner.pdf Google Scholar. 